\title{
Kansei Design with Cross Cultural Perspectives
}

\author{
Kuohsiang Chen, Shu-chuan Chiu, and Fang-chyuan Lin \\ Department of Industrial Design, National Cheng Kung University, 1 University Road, \\ Tainan 701, Taiwan \\ kchen@mail.ncku.edu.tw
}

\begin{abstract}
This study aimed to explore the cross cultural perspectives (including that of Taiwan, China, Japan and Korea) toward Kansei design using mobile phone as an example. Formal features, Kansei adjectives and the relationships between them were investigated via Kansei engineering procedures: (1) collecting mobile phone samples and Kansei words; (2) selecting mobile phone samples and Kansei words using KJ method and Factor Analysis respectively; (3) designing four sets of bilingual questionnaires with 5-point Licker Scale; (4) conducting experiments on four sites with questionnaire; (5) analyzing results using Quantification Type I. The achieved tasks include: (1) The Kansei needs of consumers from different culture background; (2) The preferred formal features of a mobile phone among different cultural background; and (3) The relationships between Kansei words and formal features for different cultural background. The results can be used as reference for designing cross-culture mobile phones as well as other closely related products.
\end{abstract}

Keywords: Cross-cultural, Culture difference, Formal features, Kansei engineering, Mobile phones.

\section{Introduction}

Accompanying with the escalation of living standard, users' expectations on surrounding products are raising as well. Functionality alone can no longer satisfy user's demands. How to increase emotional value [2] of a product plays an important role in today's business strategy. Hence, Kansei Engineering (KE), employing engineering approach, was developed to find out which design characteristics elicit particular subjective feelings from people, and then build them into a product to elicit the desired responses [10, 17, 22]. Various studies have proved the usefulness of Kansei engineering, especially in the area of visual Kansei studies [14, 17]. However, without accurate measuring by scientific instruments, the results of such studies often pointed to a vague set of product elements instead of more specific ones for evoking certain Kansei feelings.

On the other hand, various researches conducted in different regions showed different results. It indicated that different cultural origins with different traditions, custom, ethic and values may have contributed to the different findings. Apparent evidences include Italian improvisatory and romantic flair, German precise and systematic orderliness, and American innovative and rich varieties, Japanese delicate and ethereal details, and French noble and fashionable touch [24]. 


\subsection{Purposes and Objectives}

Therefore, the purposes of this study were set to explore the cross cultural perspectives toward Kansei design using mobile phones as examples. Formal features, Kansei adjectives and the relationships between them were investigated with Kansei Engineering procedures. Three objectives can be drawn as follows: (1) exploring users experience and the preferences of mobile phones among different cultural backgrounds; (2) investigating the cultural effects on users' preferences of mobile phone designs and Kansei images; and (3) generating a set of culture dimensions for Kansei design.

\subsection{Processes and Steps}

Interviews and questionnaires are conducted along with the procedures of Kansei evaluations which can be divided into five steps: (1) collecting mobile phone samples and Kansei words; (2) selecting representative mobile phone samples and Kansei words via interviewing with experienced designers and KJ method respectively; (3) extracting design elements; (4) designing four sets of bilingual questionnaires with 5point Licker Scale; (5) conducting experiments on four sites with questionnaires; and (6) analyzing results using Quantification Type I.

\subsection{Subjects and Scopes}

Top selling mobile phones from Taiwan, China, Japan and Korea are used as samples for this study. Brands include: Alcatel, Asus, BenQ, BenQ-Siemens, DoCoMo, Dopod, LG, Motorola, Nokia, OKWAP, Panasonic, Pantech, Samsung, Sharp, SonyEricsson, Toshiba, and etc.

\section{Theoretical Bases}

Related researches and literatures including cultural studies, formal features, and Kansei engineering are reviewed in order below to form the foundations for this study.

\subsection{Cultural Studies}

Hofstede [12] has conducted a cultural study on IBM's staffs from 64 countries during 1978 and 1983 and found that the differences were from different values. He then constructed them into five so-called dimensions of culture. They are: power distance, individualism vs. collectivism, masculinity vs. femininity, uncertainty avoidance, and long-term orientation. Hofstede's study [13] shown in Table 1 depicts that, compared to other three regions, Japan has the highest tendencies on individualism, masculinity and uncertainty avoidance, and the lowest on power distance; South Korea the lowest tendencies on masculinity and long-term orientation; Taiwan the lowest tendency on individualism; while China having the highest tendencies on power distance and longterm orientation, and the lowest on uncertainty avoidance. On the other hand, Barber and Badre [1], in their study of cultural characteristics of interface design, identified a 
set of frequently used and preferred interface design elements and labeled them as Culture Markers. In a study on color and culture among China, Japan, Egypt, France and United States, Boor and Russo [3] found that there were different meanings and reactions toward colors such as: red, blue, green, yellow and white among them.

Mobile phones have been shaped under different culture and, in turn, influenced the cultural settings surrounding them. For example, in Japan, Keitai, short for mobile phones, was designed as compact as possible to meet Japanese carrying needs. And in turn, it has changed the commuting culture from reading news paper, magazine or book into pressing buttons on a Keitai [12]. In Korea, that more manufacturers has formed a severe competition to rapidly react to the market demands and to offer various designs have made Korean replace their mobile more frequently than any other countries. The only similarity between Japanese and Korean is the slogan: "Everything over mobile". While the development of mobile communication is getting matured, the talking time also gets reduced in most countries except Taiwan [5]. Even though the functions on a mobile have increased to an uncountable number, to Taiwanese conversation is still the most frequently used one. To China, mobile is not only a communication devise but also a sign of grown-up. Like in Japan, the mobile has developed a so-called message culture or thumb culture in China due to the system rate policy and their fond of sending short messages in daily life.

Table 1. Hofstede's dimension of culture scales. (http://www.kwintessential.co.uk/intercultural/ dimensions.html)

\begin{tabular}{cccccc}
\hline Country & $\begin{array}{c}\text { Power } \\
\text { Distance }\end{array}$ & Individualism & $\begin{array}{c}\text { Uncertainty } \\
\text { Avoidance }\end{array}$ & Masculinity & $\begin{array}{c}\text { Long-term } \\
\text { Orientation }\end{array}$ \\
\hline Japan & 54 & 46 & 92 & 95 & 80 \\
South Korea & 60 & 18 & 85 & 39 & 75 \\
Taiwan & 58 & 17 & 69 & 45 & 87 \\
China & 80 & 20 & 30 & 66 & 118 \\
\hline
\end{tabular}

\subsection{Formal Features}

Products communicate stylistic messages via various forms and features. Chen and Owen [6] proposed a Style Description Framework (SDF) equipping designers with the abilities to analyze existing styles and to describe new styles for target markets. As the product of a SDF, a "style profile" consists of a set of polar adjective scales and associated weighting mechanisms. Within the profile, stylistic attributes -- in the form of values given on the scales -- are grouped into six categories: form elements, joining relationships, detail treatments, materials, color treatments and textures. Two weighting mechanisms, an importance index and a confidence factor, fine tune the description. The "style profile" can be used not only to communicate styles between designers and computers but also to accumulate formal style knowledge.

Following the rules of Gestalt psychology and product aesthetic, Wallace [25], in his thesis, proposed a computer system capable of generating forms conforming to both aesthetic and manufacturing requirements. It can be summarized into four parts: (1) arrangement of the components according to aesthetic rules; (2) definition of the styles according to the types of edges and corners (eg: Braun style, High-tech style or 
Art Deco style); (3) configuration of the product modules and components; and (4) graphics, textures and color treatments of the product surface.

Breemen [4] classified the aesthetic characteristics of product forms into three levels according to their contributions. Among them, form detail, constructing method, color, material, texture and light have the most contribution to product aesthetics. Product overall shape comes the second while the geometric space coordinate positioning having the least effect on product aesthetics.

\subsection{Kansei Engineering}

Emotional consuming is becoming a trend in global market competition. Consumers pay more and more attention on personal emotional feelings while buying things, which makes consuming-style change significantly [9]. Kansei Engineering (KE), a consumer-oriented new product development technique shaped to meet such trend, emphasizes the exploration of relationships between people's emotional feelings and artifacts' characteristics [7, 18, 20, 21]. Hence, it has become an important topic for user-oriented product development and design and a key factor in elevating design competence. Recent studies in this area have accumulated fruitful findings and demonstrated its value in product positioning during new product development and design stage $[15,19]$. However, most of the studies focused on the mappings between single Kansei word and design elements [11], and left multi-Kansei evaluation intact.

In general, there are five steps in a Kansei Engineering process. (1) Selecting Kansei words - factor analysis or KJ method can be employed. (2) Selecting representative samples - those demonstrating well the Kansei words decided above are to be selected as samples. (3) Extracting essential form characteristics - experienced product designers can be called up to help extract most prominent design components (equivalent to items in KE) which contribute best to the Kansei words decided above. Possible design options (equivalent to categories in $\mathrm{KE}$ ) can be further set for these components. (4) Constructing 3D digital samples - product pictures are generated for later Kansei evaluation. (5) Kansei evaluation - subjects are asked to evaluate the Kansei words against the product pictures using either Likert scale or Semantic Differential scale. Data collected are then analyzed with Quantitative Theory Type I to establish the relationships between each Kansei word and design elements.

\section{Processes}

The study was conducted with the following steps : (1) collecting samples and Kansei words; (2) selecting representative samples and Kansei words; (3) extracting design elements; (4) designing questionnaires; (5) conducting experiments with questionnaire; and (6) analyzing results using Quantification Type I.

\subsection{Collecting Samples and Kansei Words}

Mobile phone models marketed in these four nations are extensively collected, roughly 100 pieces. Four criteria used for screening the models are: (1) design paradigm models chosen should be generally acknowledged as design paradigm with high value, as well as high selling volume and broadly discussed; (2) culture breadth - models 
chosen should cover all of the four regions and be highly regarded; (3) style range models chosen should cover a range of various styles; and (4) progressive trend models chosen should be able to exhibit the progressive trend of mobile phone design within 2005 and 2006. Figure 1 shows some examples of them. Brands include: Alcatel, Arcoa, Asus, BenQ, BenQ-Siemens, DoCoMo, Dopod, Eten, Gigabyte, KDDI, LG, Motorola, Nokia, OKWAP, Panasonic, Pantech, Samsung, SCH, Sharp, SonyEricsson, Toshiba and etc.

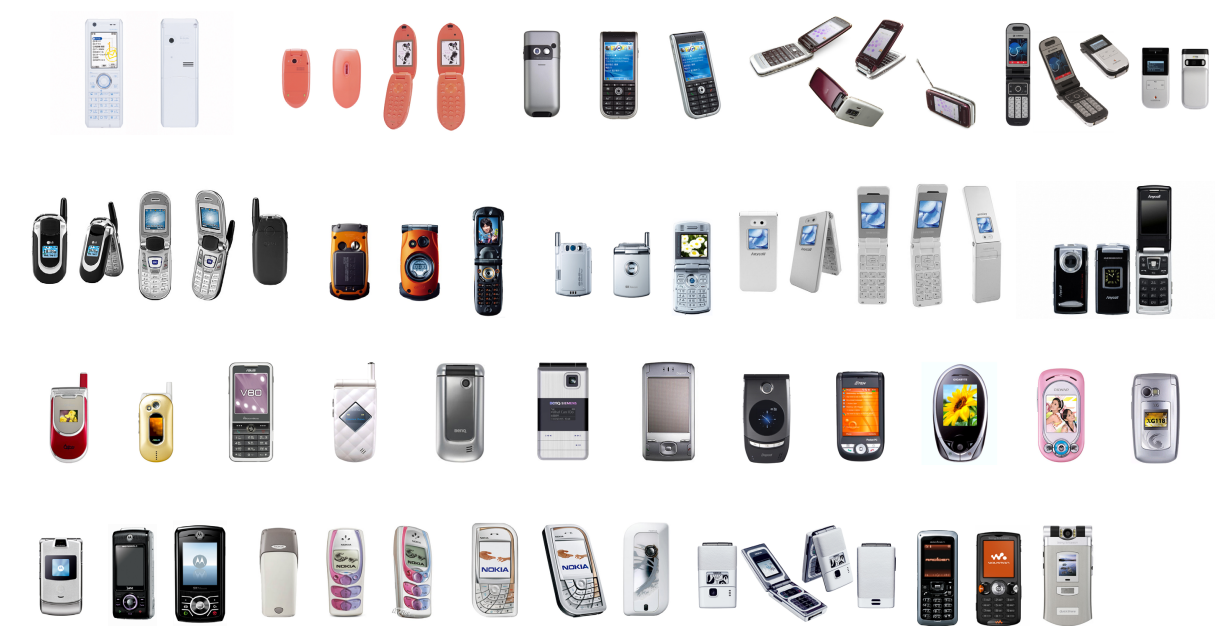

Fig. 1. Mobile phones currently selling in Japan, South Korea, Taiwan and China (partial)

The most popular Kansei words (top 20 per country) used in describing mobile phones are collected from web pages and magazines published in theses four nations (Table 2). The top word of each cell appears in the original language while the bottom one the translation. For example, Chinese (traditional, simplified or Japanese Kanji) are the original language for all regions except South Korea. In other words, Chinese is the translation to South Korea while English the translation to the rest of the regions.

\subsection{Selecting Representative Samples and Kansei Words}

Representative mobile phones were selected after interviews with experienced mobile phone designers and users to cover all of the features usually exhibited on it. Figure 2 shows part of the chosen samples.

Interviews were designed into two versions: (1) in-depth interview for gathering knowledge and viewpoints from design experts, and (2) contextual exploration for gathering consumption and use experience from experienced users. The leading questions for design experts contain: personal experiences in mobile phone design, design strategy and corporate image of the belonging company (or studio), and design approaches applied against culture issues, while that for experienced users containing: personal experiences in owning and using mobile phones, and culture cognition of the mobile phones. 
Table 2. Kansei words collected from Japan, South Korea, Taiwan and China

\begin{tabular}{|c|c|c|c|}
\hline Japan & South Korea & Taiwan & China \\
\hline $\begin{array}{c}\text { 質感的 } \\
\text { Characteristic }\end{array}$ & $\begin{array}{l}\text { Innovative } \\
\text { 創新的 }\end{array}$ & $\begin{array}{l}\text { 科技的 } \\
\text { Technical }\end{array}$ & $\begin{array}{l}\text { 数码的 } \\
\text { Digital }\end{array}$ \\
\hline $\begin{array}{c}\text { 機能的 } \\
\text { Functional }\end{array}$ & $\begin{array}{c}\text { Thin } \\
\text { 超薄的 }\end{array}$ & $\begin{array}{c}\text { 時尚的 } \\
\text { Fashionable }\end{array}$ & $\begin{array}{l}\text { 便携的 } \\
\text { Handy }\end{array}$ \\
\hline $\begin{array}{c}\text { 快適的 } \\
\text { Cozy }\end{array}$ & $\begin{array}{l}\text { Compact } \\
\text { 簡潔的 }\end{array}$ & $\begin{array}{c}\text { 品味的 } \\
\text { Taste }\end{array}$ & $\begin{array}{l}\text { 顶级的 } \\
\text { Top Class }\end{array}$ \\
\hline $\begin{array}{l}\text { 極簡的 } \\
\text { Minimal }\end{array}$ & $\begin{array}{c}\text { Fashionable } \\
\text { 時尚的 }\end{array}$ & $\begin{array}{l}\text { 簡約的 } \\
\text { Terse }\end{array}$ & $\begin{array}{l}\text { 精巧的 } \\
\text { Exquisite }\end{array}$ \\
\hline $\begin{array}{l}\text { 魅力的 } \\
\text { Charming }\end{array}$ & $\begin{array}{l}\text { Stylish } \\
\text { 風格的 }\end{array}$ & $\begin{array}{l}\text { 精緻的 } \\
\text { Delicate }\end{array}$ & $\begin{array}{c}\text { 潮流先驱的 } \\
\text { Trend Pioneering }\end{array}$ \\
\hline $\begin{array}{l}\text { 便利的 } \\
\text { Handy }\end{array}$ & $\begin{array}{l}\text { Colorful } \\
\text { 鮮豐的 }\end{array}$ & $\begin{array}{l}\text { 耐用的 } \\
\text { Durable }\end{array}$ & $\begin{array}{c}\text { 个性的 } \\
\text { Particular }\end{array}$ \\
\hline $\begin{array}{l}\text { 個性的 } \\
\text { Particular }\end{array}$ & $\begin{array}{l}\text { Handy } \\
\text { 便利的 }\end{array}$ & $\begin{array}{c}\text { 嶄新的 } \\
\text { Fresh }\end{array}$ & $\begin{array}{l}\text { 轻薄的 } \\
\text { Flimsy }\end{array}$ \\
\hline $\begin{array}{l}\text { 可愛的 } \\
\text { Cute }\end{array}$ & $\begin{array}{l}\text { Unique } \\
\text { 獨特的 }\end{array}$ & $\begin{array}{c}\text { 流行的 } \\
\text { Fashionable }\end{array}$ & $\begin{array}{c}\text { 流行的 } \\
\text { Fashionable }\end{array}$ \\
\hline $\begin{array}{l}\text { 輕薄的 } \\
\text { Flimsy }\end{array}$ & $\begin{array}{l}\text { Functional } \\
\text { 功能的 }\end{array}$ & $\begin{array}{l}\text { 俐落的 } \\
\text { Tailored }\end{array}$ & $\begin{array}{c}\text { 抢眼的 } \\
\text { Eye-Catching }\end{array}$ \\
\hline $\begin{array}{l}\text { 時代的 } \\
\text { Modern }\end{array}$ & $\begin{array}{l}\text { Smart } \\
\text { 智慧的 }\end{array}$ & $\begin{array}{l}\text { 獨特的 } \\
\text { Unique }\end{array}$ & $\begin{array}{c}\text { 不俗的 } \\
\text { Not Hackneyed }\end{array}$ \\
\hline $\begin{array}{c}\text { 先進的 } \\
\text { Advanced }\end{array}$ & $\begin{array}{l}\text { High Tech } \\
\text { 高科技的 }\end{array}$ & $\begin{array}{l}\text { 個性的 } \\
\text { Particular }\end{array}$ & $\begin{array}{c}\text { 智能的 } \\
\text { Intelligent }\end{array}$ \\
\hline $\begin{array}{l}\text { 獨創的 } \\
\text { Unique }\end{array}$ & $\begin{array}{l}\text { Curvaceous } \\
\text { 曲線美的 }\end{array}$ & $\begin{array}{l}\text { 簡潔的 } \\
\text { Compact }\end{array}$ & $\begin{array}{l}\text { 经典的 } \\
\text { Classic }\end{array}$ \\
\hline $\begin{array}{l}\text { 簡單的 } \\
\text { Simple }\end{array}$ & $\begin{array}{l}\text { Smooth } \\
\text { 流暢的 }\end{array}$ & $\begin{array}{l}\text { 輕巧的 } \\
\text { Light }\end{array}$ & $\begin{array}{l}\text { 精品的 } \\
\text { Fine }\end{array}$ \\
\hline $\begin{array}{l}\text { 安心的 } \\
\text { Relieved }\end{array}$ & $\begin{array}{l}\text { Palmary } \\
\text { 出眾的 }\end{array}$ & $\begin{array}{l}\text { 可愛的 } \\
\text { Cute }\end{array}$ & $\begin{array}{c}\text { 内敛的 } \\
\text { Restrained }\end{array}$ \\
\hline $\begin{array}{c}\text { 氣氛的 } \\
\text { Atmospheric }\end{array}$ & $\begin{array}{l}\text { Shining } \\
\text { 閃耀的 }\end{array}$ & $\begin{array}{l}\text { 經典的 } \\
\text { Classic }\end{array}$ & $\begin{array}{l}\text { 奢华的 } \\
\text { Luxurious }\end{array}$ \\
\hline $\begin{array}{l}\text { 精美的 } \\
\text { Artistic }\end{array}$ & $\begin{array}{l}\text { Cute } \\
\text { 可愛的 }\end{array}$ & $\begin{array}{l}\text { 超薄的 } \\
\text { Thin }\end{array}$ & $\begin{array}{l}\text { 优雅的 } \\
\text { Elegant }\end{array}$ \\
\hline $\begin{array}{c}\text { 華麗的 } \\
\text { Gorgeous }\end{array}$ & $\begin{array}{l}\text { Charming } \\
\text { 迷人的 }\end{array}$ & $\begin{array}{c}\text { 高級的 } \\
\text { High Class }\end{array}$ & $\begin{array}{c}\text { 可爱的 } \\
\text { Cute }\end{array}$ \\
\hline $\begin{array}{l}\text { 表現力的 } \\
\text { Expressive }\end{array}$ & $\begin{array}{c}\text { Sporty } \\
\text { 運動的 }\end{array}$ & $\begin{array}{l}\text { 年輕的 } \\
\text { Young }\end{array}$ & $\begin{array}{c}\text { 另类的 } \\
\text { Out of Character }\end{array}$ \\
\hline $\begin{array}{l}\text { 高級感的 } \\
\text { High Class }\end{array}$ & $\begin{array}{c}\text { Crazy } \\
\text { 瘋狂的 }\end{array}$ & $\begin{array}{c}\text { 商務的 } \\
\text { Commercial }\end{array}$ & $\begin{array}{c}\text { 动感的 } \\
\text { Dynamic }\end{array}$ \\
\hline $\begin{array}{l}\text { 直線的 } \\
\text { Linear }\end{array}$ & $\begin{array}{l}\text { Magic } \\
\text { 神奇的 }\end{array}$ & $\begin{array}{l}\text { 休閒的 } \\
\text { Leisure }\end{array}$ & $\begin{array}{c}\text { 酷派的 } \\
\text { Cool }\end{array}$ \\
\hline
\end{tabular}

Each interview lasts about 80 minutes, including: introduction and camera setting (10 min.), interview (30 min.), experiment (30 min.) applying Evaluation Grid Method [23], following up questions ( $5 \mathrm{~min}$.) and summing up (5 min.). Owing to the limited budget, interviews were only conducted in Taiwan. 
KJ method was employed to group the representative Kansei words. Those ones which share higher popularity among different regions are chosen. Table 3 shows the result of the process.

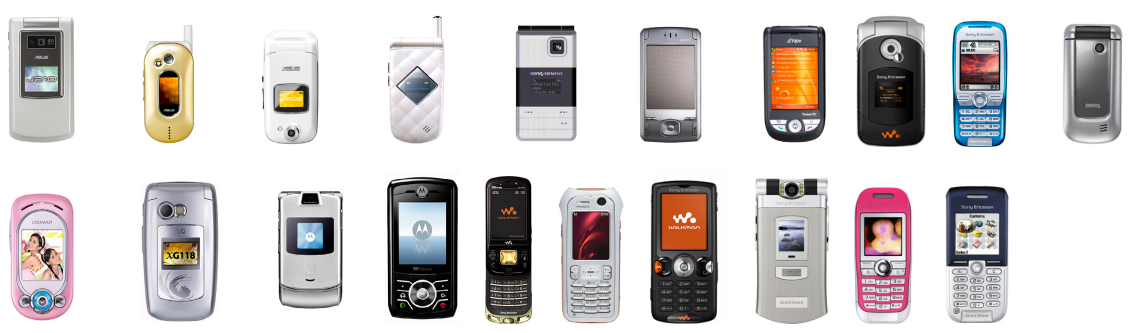

Fig. 2. Representative mobile phones chosen for the Kansei evaluation (partial)

\subsection{Extracting Design Elements}

A list of design components (equivalent to items in $\mathrm{KE}$ ) and design options (equivalent to categories in KE) was compiled after a series of in-depth interviews with experiment applying Evaluation Grid Method conducted for design experts. Table 4 shows the results.

\subsection{Designing Questionnaires}

Before conducting the experiment on site, four sets of bilingual questionnaires were designed. Participants included design students and consumers in the mobile phone stores. The contents of the questionnaire consist of two parts: Kansei related and preferences related. Likert scale of 5 levels was used for the scoring.

Table 3. Representative Kansei words chosen for latter use

\begin{tabular}{|l|l|l|l|}
\hline Japan & South Korea & Taiwan & China \\
\hline $\begin{array}{l}\text { 可愛的 } \\
\text { Cute }\end{array}$ & $\begin{array}{l}\text { Cute } \\
\text { 可愛的 }\end{array}$ & $\begin{array}{l}\text { 可愛的 } \\
\text { Cute }\end{array}$ & $\begin{array}{l}\text { 可爱的 } \\
\text { Cute }\end{array}$ \\
\hline $\begin{array}{l}\text { 輕薄的 } \\
\text { Flimsy }\end{array}$ & Thin & 超薄的 \\
Thin & 轻薄的 \\
\hline 薄的 & Flimsy \\
\hline Modern & Fashionable & 時尚的 & 潮流先驱的 \\
時尚的 & Fashionable & Trend Pioneering \\
\hline 便利的 & Handy & 耐用的 & 便携的 \\
Handy & 便利的 & Durable & Handy \\
\hline 機能的 & Functional & 科技的 & 数码的 \\
Functional & 功能的 & Technical & Digital \\
\hline & High Tech & 嶄新的 & \\
& 高科技的 & Fresh & \\
\hline & Innovative & & \\
\hline
\end{tabular}


Table 4. Design Elements (Items and Categories)

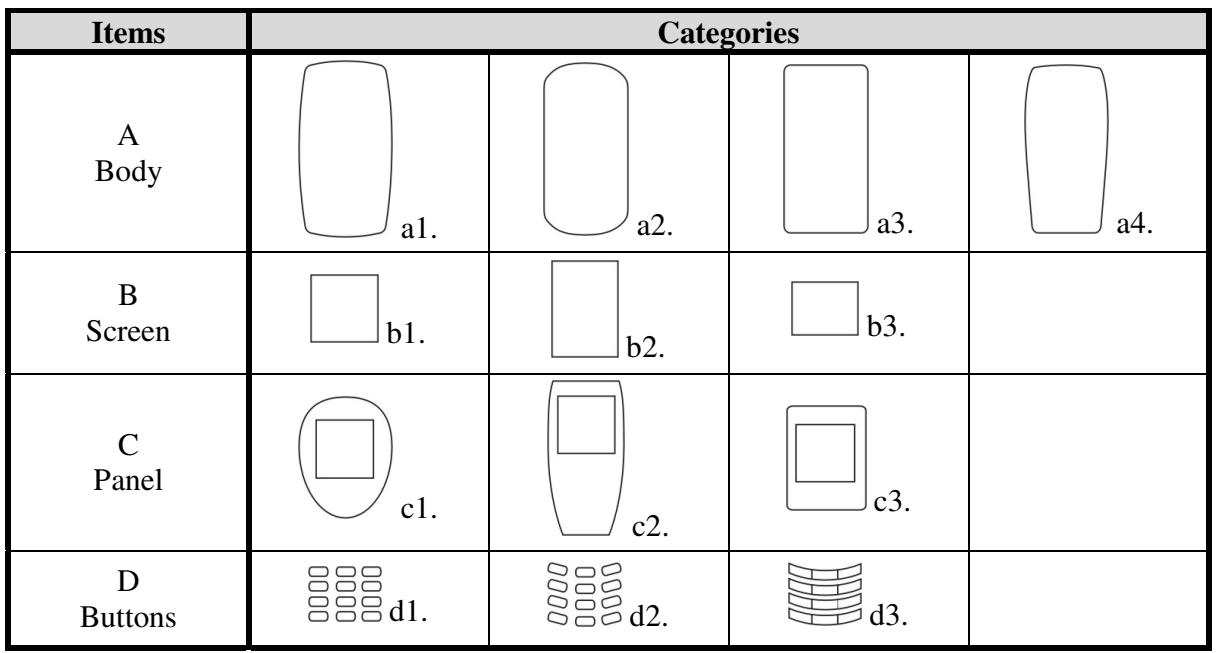

\subsection{Conducting Experiments}

Questionnaires are then used with the Kansei evaluation experiments. Results are shown and analyzed in the following sections.

\subsection{Analyzing Results}

From Table 3, we discovered that some Kansei words share high similarity among the four regions while some are uniquely used for a single region. The former include: Cute, Thin (Flimsy), Fashionable (Modern or Trend Pioneering), Handy, Functional, and etc. while the later covering Expressive, Sporty, Young, Out of Character, Crazy, Commercial, Dynamic, Linear, Magic, Leisure, Cool, and etc.

From Table 4, the design elements extracted from design experts show that there are four major parts of a mobile phone contributing to Kansei image. They are: body, screen, panel and buttons.

\section{Conclusions and Discussions}

The Kansei needs of consumers from different culture backgrounds are different due to their diverseness in use habit. For example, in Japan, Keitai, short for mobile phones, was designed as compact as possible to meet Japanese carrying needs. And in turn, it has changed the commuting culture from reading news paper, magazine or book into pressing buttons on a Keitai. In Korea, that more manufacturers has formed a severe competition to rapidly react to the market demands and to offer various designs have made Korean replace their mobile more frequently than any other countries.

The preferred formal features of a mobile phone among different cultural backgrounds are different too. The only similarity between Japanese and Korean is the 
slogan: "Everything over mobile". While the development of mobile communication is getting matured, the talking time also gets reduced in most countries except Taiwan. Even though the functions on a mobile have increased to an uncountable number, to Taiwanese conversation is still the most frequently used one. To China, mobile is not only a communication devise but also a sign of grown-up. Like in Japan, the mobile has developed a so-called message culture or thumb culture in China due to the system rate policy and their fond of sending short messages in daily life. The results can be used as reference for designing cross-culture mobile phones as well as other closely related products.

Acknowledgments. Thanks to the financial support of National Science Council, Taiwan for this research under the contract number: NSC-95-2221-E-006-141.

\section{References}

1. Barber, W., Badre, A.: Culturability: The Merging of Culture and Usability. In: Proceedings of the 4th Conference on Human Factors and the Web, Basking Ridge, New Jersey (1998)

2. Barlow, J., et al.: Emotional Value: Creating Strong Bonds With Your Customers, BerrettKoehler Pub (2000)

3. Boor, S., Russo, P.: How Fluent Is Your Interface? Designing for International Users, INTERCHI '93 (1993)

4. van Breemen, E.J.J., Slamet, S.: The Role of Shape in Communicating Designers' Aesthetic Intents. In: Proceeding of the 1999 ASME Design Engineering Technical Conferences, Las vegas, Nevada (1999)

5. Chen, H.P.: 2003. Mobile Cultural Revolution. Taipei: E-earthgeo (2003)

6. Chen, K., Owen, C.L.: Form Language and Style Description. Design Studies 18, 249-274 (1997)

7. Chen, K., Shing-Sheng G., Yi-Shin D., Yu-Ming C.: A Method for Converting Sensibility into Sense. Industrial Design, vol 29(1), pp. 2-16, Ming-Chi Institute of Technology, Taiwan (2000)

8. Cleveland, D., Cleveland, N.: Eyegaze eyetracking system. Imagina: Images Beyond Imagination. Eleventh Monte-Carlo International Forum on New Images, LC Technologies, Inc. (1992)

9. Gobe, M., et al.: Emotional Branding: The New Paradigm for Connecting Brands to People, Allworth Press (2001)

10. Harada, A.: The Parallel Design Methodology in the KANSEI Engineering. Report of Modeling the Evaluation Structure of Kansei, pp. 309-316 (1998)

11. Heo, S., Harada, A.: Research on Characteristics of Kansei Reaction toward Images, 4th Asian Design Conference, Japan (1999)

12. Hofstede, G.: Cultures and organizations: Software of the mind. McGraw-Hill, London (1997)

13. http://www.kwintessential.co.uk/intercultural/dimensions.html

14. Jindo, T., Hirasago, K., Nagamachi, M.: Development of design Support system for office chairs using 3-D graphics. International Journal of Industrial Ergonomics 15, 49-62 (1995)

15. Lee, E., Lee, H., Kim, M.: The Effects of Visual and Auditory Information as a Tool of Emotional Value Assessment, 4th Asian Design Conference, Japan (1999) 
16. Liu, L.E.: Tokyo-Myrtle-Myth - Er's Japanese Affection. Taipei: Wheat Fields Publisher (2002)

17. Matsubara, Y., Nagamachi, M.: Hybrid Kansei Engineering System and design support. 1997) 19, 81-92 (1997)

18. McDonagh, D.: Visual Product Evaluation: Exploring Users Emotional Relationships with Products. Applied Ergonomics 33(3), 231-240 (2002)

19. Miyazaki, K., Matsubara, Y., Nagamachi, M.: A Modeling of Design Recognition in Kansei Engineering. Japanese Journal of Ergonomics 29(Special), 196-197 (1993)

20. Nagamachi, M.: Kansei Engineering. Tokyo: Kaibundo, Japan (1989)

21. Nagamachi, M.: Kansei Engineering: A consumer-oriented technology. In: Bradley, Hendrick (eds.) Human Factors in Organizational Design and Management - IV, pp. 467 472. Elsevier Science, Amsterdam (1994)

22. Nagamachi, M.: Kansei Engineering: A new ergonomic consumer-oriented technology for product development. International Journal of Industrial Ergonomics 15, 3-11 (1995)

23. Sanui, J.: Visualization of users' requirements: Introduction of the Evaluation Grid Method. Proceedings of the 3rd Design \& Decision Support Systems in Architecture \& Urban Planning Conference 1, 365-374 (1996)

24. Tsai, Z.W.: A Study on Product Image Language - Using Native Image as Example. Master Thesis, National Cheng Kung University, Tainan, Taiwan (1994)

25. Wallace, D.D.: A Computer Model of Aesthetic Product Design: an Approach. Master Thesis of Science in Mechanical Engineering at MIT, pp. 42-44 (1991) 